\title{
Bringing the calf back from the dead: video activism, the politics of sight and the New Zealand dairy industry
}

Lynley Tulloch ${ }^{1 *}$ (D) and Paul Judge ${ }^{2}$

\author{
* Correspondence: \\ tulloch.time@gmail.com \\ ${ }^{1}$ Independent Consultant, Auckland, \\ New Zealand \\ Full list of author information is \\ available at the end of the article
}

\begin{abstract}
In New Zealand one of the most significant animal rights issues is the systemic cruelty inherent in the dairy industry. This article presents a review of video activism as a strategy by activists in New Zealand to educate the public about the brutal and oppressive realities of dairy practices. To illustrate we offer a case study of an antidairy campaign in 2015 that was based on activist video work. This campaign was led by key animal rights groups SAFE and Farmwatch and was called The Dark Side of Dairy. In this case, video footage captured by activists was used to provide counter narratives to the dominant discourses of dairying and to educate the public about their consumption practices. We argue that dominant discourses of dairying are powerful shapers of public consciousness and based on welfarist ideology and myths of the rural Romantic Arcadia. To illustrate the strength of these dominant understandings we employ critical discourse analysis (CDA) and semiotic analysis. In teasing out the ways in which discourses of dairy farming have been constructed in New Zealand, we demonstrate the power of political forces in preserving the status quo around dairying. This paper concludes that the role of animal rights video activism lies primarily in educating the public to think more deeply and critically about human-animal relations and the depravations of dairy farming. It is the basis for a pedagogy of conscientization. We conclude that conscientization of the underpinning exploitative relations of animal agriculture can occur with the aid of witness to the animal's suffering conveyed through the medium of video.
\end{abstract}

Keywords: Video activism, Animal rights, Dairy industry, Conscientization, Critical discourse analysis, Semiotic analysis, Farmwatch, SAFE. Industrial farming, Animal agriculture, Transformative pedagogy

\section{Background}

The value of undercover video as a tool for animal rights activists in exposing animal cruelty is immense. Video footage provides evidence of both deliberate and isolated animal cruelty within the farming industry, as well as institutionalised forms of abuse. It can be used not only for educating the public, but also as part of investigations and legal evidence.

In 2015 animal rights group Farmwatch launched an investigation into the dairy industry, with a particular focus on the issue of bobby calves (Farmwatch, 2015). What they discovered was instances of extreme cruelty resulting in the horrific suffering of

(c) The Author(s). 2018 Open Access This article is distributed under the terms of the Creative Commons Attribution 4.0 International License (http://creativecommons.org/licenses/by/4.0/), which permits unrestricted use, distribution, and reproduction in any medium, provided you give appropriate credit to the original author(s) and the source, provide a link to the Creative Commons license, and indicate if changes were made. 
calves. They also found evidence of widespread institutionalized cruelty and captured aspects of this on film. Their work was used in a campaign launched by animal rights group Save Animals from Exploitation (SAFE) called The Dark Side of Dairying.

In this paper we propose to illustrate how this campaign used undercover footage of animal suffering within the dairy farming industry to provide testimony for public inspection. In doing so Farmwatch was attempting to convey the systemic nature of dairying abuse, by presenting footage as our "substitute eyes and ears" (Peters, 2001). The overall aim is conscientization of the public with regards to institutionalised cruelty in farming practices. Using video footage of animal cruelty, both Farmwatch and SAFE were attempting to counter the official welfarist positioning of governmental policy and the cultural narrative of rural life as an Arcadian paradise. These discourses have been produced and reproduced by media, legal and economic institutions.

These discourses are strongly entrenched in the public psyche in New Zealand and we explore these in this article. They form the dominant ideological position within which animal lives are thought about, and they have direct implications. The ideological configuration or farming as an 'economic necessity' where animals are well cared for in an idyllic rural landscape is fundamental to a public consensus that ensures its continuation. This dominant view rests on the fundamental assumptions of animal-as-commodity (market exchange value) and animal-as-object (of human control rather than subject of his/her own existence). The following sections unpack the way that dairying has been historically constructed in New Zealand in order that we can more fully engage with the intent of video activist work in this area.

In mirroring the aims of animal rights focused video activism this article thus employs critical discourse analysis (CDA) and semiotic analysis to analyze discourse in policy and industry settings as it pertains to farming dairy animals in New Zealand. The CDA drawn on here derives from post structuralist theory, particularly the work of Michel Foucault (1972). Foucault provides a way of analysing discursive positionings on farming in a genealogical sense, tracing their historical construction according to the political and economic context of their formation. Discourses are ideological configurations or 'truth models' about the economic, social and natural worlds. Once a truth model becomes 'naturalised' and taken for granted it develops the character of inevitability.

With respect to the dairy industry, video activism aims to highlight common sense understandings of dairy farming that have become naturalised and used by governments to establish control over populations. For example, one common sense understanding is that bobby calves need to be killed to procure their mothers' milk. They are superfluous to the requirements of the dairy industry (economic rationale: bobby calf reduced to a waste product), and so must be dispatched of humanely (welfarist position: we may kill calves for human interest, but it must be done with their welfare in mind). Our understanding of dairy cow and bobby calf is discursively constructed in the following way: the dairy cow has a specific purpose as it has been bred to produce milk for human consumption; the bobby calf is a by-product of this process and not useful after his birth has produced lactation in the dairy cow.

Thus, the dairy cow and calf are constituted by discourse; we make meaning of their existence through ideas and practices. Foucault writes, "discourses are practices that systematically form the objects of which they speak...discourses are not about objects, 
they do not identify objects, they constitute them and in doing so conceal their own invention" (Foucault, 1972, p.49). In this sense discourse is a "system of meaning that constitutes institutions, practices and identities in contradictory ways" (Larner, 2000). Dairy industry practices, including the breeding, milking and killing of animals, are highly industrialised and unnatural processes (Armstrong, 2017). Yet through media and legal policy documents dairying is discursively constituted as natural or 'the way things are'. This naturalisation of dairy farming links to Arcadian imagery of natural and organic farm life, the farmer in harmony with nature and intimately caring for the animals, as evident in the Fonterra television commercials (TVCs) discussed below.

In this article we argue that video activism in New Zealand seeks to counter the dominant discursive positioning around dairy practices by offering a counter-narrative. This counter-narrative is based on animal-rights theory and proposes social change in our economic production and consumption practices. Animal rights theory is a marginalised view in New Zealand but, as demonstrated in this paper, video activism provides an opportunity for transformative education.

\section{Dairying and video activism Video activism}

This section describes the campaign by SAFE and Farmwatch in 2015 called "The Dark Side of Dairying". It also examines further video work in 2016 that aimed to provide further video footage of enduring dairy cruelty.

As part of the 2015 investigation Farmwatch captured the hideous suffering of calves in an abattoir. It was first shown on Sunday, a New Zealand current affairs programme, on November 29, 2015. More footage was shown in a video released by Farmwatch after the show. It included scenes of cows being separated from their calves; calves and cows mishandled on the farm; calves in pens waiting hours in the heat for pick up; calves being thrown on trucks; and at the abattoir where they were kicked, beaten, and hurled on concrete floors. (Farmwatch, 2015). This footage can be viewed here: https://vimeo.com/146749967 The footage went viral on news sites and social media. SAFE placed a graphic campaign in The UK Guardian with an image of a dead bobby calf in a glass of milk stained with blood. It contained the message that New Zealand dairy was "contaminated with cruelty". It ran once in the hard copy and online for two weeks.

Activist camera-witnessing provides a form of testimony to the brutality and institutionalized cruelty experienced by dairy animals caught up in the animal industrial complex. This video explains the work of Farmwatch in exposing the abuse of bobby calves at Down Cow Slaughterhouse: https://vimeo.com/171467454 In this video Farmwatch spokesperson John Darroch explains:

"It was quite a dramatic sight. We saw a massive pile of calf skins at a loading dock. And these were the skins of calves after they'd been killed and they had just been left out on the loading dock and the smell kind of immediately hit us. And then we drove around the side and we saw that there was a pen full of live calves, and this was a Sunday afternoon, the slaughterhouse was not operating. Who knows when these calves had been picked up. Who knows how long they had been sitting there. And the slaughterhouse wasn't going to open until the following morning. So these calves had 
not only been left at the side of the road, thrown into a truck, driven all around the Waikato, they'd then been left in the yards at the slaughterhouse for probably twelve hours or more. And it was at that kind of stage that we knew we had to get footage from inside this place. If this was the kind of thing that was happening routinely we had to get inside behind closed doors where they thought people were not watching". John Darroch, 2015.

In the above passage (and accompanying video) we get a behind-the-scenes look at the work of activists in uncovering the brutality visited upon young defenceless calves by the dairy industry. The activist, putting their own safety in jeopardy, is witness to what is hitherto made invisible through physical barriers and powerful ideological mechanisms described above. Such videos are used by activists for educational purposes, to raise awareness and stimulate public discussion and debate around the ethics of dairying. This is the beginning point for the process of conscientization, a form of transformative educational pedagogy and a key project of animal rights activism.

The message is that cruelty within dairy is not going to go away through increased welfare standards - it is part of the industry, built into its infrastructure. SAFE and Farmwatch are not seeking to improve welfare conditions for animals per se. Higher animal welfare standards and practices are, of course, always preferable to an animal experiencing increased levels of suffering due to non-compliance. However, improving animal welfare standards will never be enough. Instead, they take an animal rights position, whereby the animal is not regarded as human property but rather as a sentient being with the right to live life on his/her own terms. An animal rights position extends the notion of rights to animals who are considered to have inherent value and interests of their own (Francione, 1995).

Farmwatch's video activism aims to counter these dominant cultural narratives of welfarism and rural Arcadian paradise through making visible the suffering experienced by farmed animals. The 2015 campaign framed the experience of dairy animals in New Zealand within a counter-cultural narrative that rejects the 'animal as object for human consumption' to 'animal as the subject of their own existence'.

John Darroch, spokesperson and volunteer investigator for Farmwatch explains the educational intent behind the videos:

The key reason for Farmwatch's existence is to show the public the reality of animal agriculture in New Zealand. We hope that our videos will serve as a counterpoint to industry propaganda. We view visual media as a uniquely useful tool through which to communicate to the public. In our videos we attempt to place the animal front and centre. It is the experience of farm animals which is missing from public discourse and understanding of farming. Our hope is that our videos will impact the public, forcing them to consider how it is that animal products are produced. Through videos we hope to inform the public about the untold suffering endured by animals in New Zealand.

-John Darroch, 2018

Farmwatch videos have been especially hard-hitting and, as mentioned above, provide a counter to the tales of rural idyll, well-cared for cows and technologically savvy farming practices. Published on the SAFE Facebook page, they have been viewed millions of 
times by a global audience. This video of a cow being dragged by a hip-clamp had upwards of 22 million views on the SAFE Facebook page https://vimeo.com/189743212/ 42d3ab19a8.

The video of a calf being dragged away from her mother was taken by Farmwatch in 2016. https://vimeo.com/263823237/4a503c4dab. The cow's distress was evident as she followed the calf closely. Coupled with the calf mistreatment, these kind of videos can be instrumental in revealing the institutionalized cruelty in dairying. It is of significance to note that this footage was taken from the roadside.

Here is another example of roadside footage taken by Starfish Bobby Calf Project: https://vimeo.com/264346996 It was viewed and shared over 143, 500 times on social media. While not graphic in nature, it demonstrates a heavy-handed farmer who is handling a new born calf and cow roughly. This runs counter to the claims in the Fonterra commercials of a mutually respectful relationship between the farmer and the animals in his 'care'.

Safe and Farmwatch have worked successfully together with Starfish Bobby Calf Project, a small grassroots activist group that was founded by the authors. Starfish has two broad aims that converge with those of the animal rights movement: gaining publicity and challenging conventional thinking about how we treat non-human animals. Through the rescue of a small number of bobby calves, Starfish aims to bring their sentience and plight to the attention of the public. Farmwatch has supported Starfish by making footage of the calves which has been disseminated to the public through SAFE. The activist project of Starfish aims to highlight the sentience of the suffering animal trapped in the machine of industrial farming precisely in the hope that the demand for animal products is reduced. This is a goal Starfish has in common with Farmwatch and SAFE.

The strength of SAFE, Farmwatch and Starfish in working together has enabled a powerful combination of strategies that use video as a platform to convey the message of both institutionalised cruelty in dairying and the sentience of the dairy animal.

An example of video footage taken of Starfish calves and put together by Farmwatch can be found here: https://vimeo.com/154545965.This video highlights the purpose of Starfish and showcases the calves' personalities.

\section{Background to the New Zealand dairy industry}

This section is an overview of dairying in New Zealand and provides the political and economic contextual backdrop to this paper. It briefly covers the governing bodies and legalities that manage the dairy industry and describes the systemic cruelty inherent in dairy farming. These bodies have a value system towards animals and their use in the agricultural system that is in stark opposition to that of Farmwatch, SAFE and Starfish. As discussed below, official legal discourse on dairying is based on welfarist and instrumentalist ideologies toward animals. In presenting evidence of cruelty through video footage, animal rights activists must ultimately enter an ideological battle with the existing legalities and governing bodies that present dairy farming as a legitimate economic and cultural activity.

The Ministry for Primary Industries (MPI) is New Zealand's public service department whose role is to oversee, regulate and manage primary industries including farming. They are clear about the significance of dairying to New Zealand: "Dairy is 
New Zealand's largest goods export industry. In the 2015/16 season there were 5 million lactating dairy cows in New Zealand and each would have given birth to a calf in order to produce milk" (Ministry for Primary Industies, 2017, p. 8). It is the world's ninth largest producer of milk, exporting 95\% of milk overseas (Gray \& Le Heron, 2010). The dairy industry also provides employment for 47,310 people - 33,750 of whom work on the farm (Livestock Improvement Corporation Limited \& DairyNZ Limited, 2017).

The dairy industry in New Zealand has grown significantly in the last two decades, despite recent small fluctuations in cow population. In the 2016/17 season there were $4,861,324$ dairy cows in New Zealand (Livestock Improvement Corporation Limited \& DairyNZ Limited, 2017). These animals produced over 20 million litres of milk in 2016 and are predominantly made up of 478\% Holstein -Friesian/Jersey crossbreed, 33\% Holstein Friesian, 9.3\% Jersey and 0.6\% Ayrshire (Livestock Improvement Corporation Limited \& DairyNZ Limited, 2017). To illustrate the level of intensification in dairy farming, statistics from the Ministry for the Environment and Statistics New Zealand show that: "Dairy cattle numbers increased 539 percent $(616,831)$ in Southland, 490 percent $(1,041,501)$ in Canterbury, and 368 percent $(302,806)$ in Otago between 1994 and 2015." (Ministry for the Environment.; Statistics New Zealand 2018).

The growth and intensification of dairy farming as an industry in New Zealand has occurred through an increase in the number of dairy cows per hectare and the production per cow (Mulet-Marquis \& Fairweather, 2008). Mulet-Marquis and Fairweather argue that it is through these intensification processes that the dairy industry has been able to compete on the global market. Dairy contributes $\$ 8$ billion to New Zealand's GDP with $90 \%$ of its dairy production being exported. In 2016 dairy was the country's largest export sector (18\% of total goods and services) being worth $\$ 12.4$ billion in 2016. The top five markets are China, US, United Arab Emirates, Australia and Japan (Dairy Companies Association of NZ, 2018).

The importance of the perception of good animal welfare standards among animals especially those as vulnerable as bobby calves - is an important economic imperative for MPI. High animal welfare standards in the dairy industry are critical to its success in a global market. MPI states that, "New Zealand's reputation for high levels of animal welfare has helped secure access to markets internationally. Our economy depends on animals" (Ministry for Primary Industries, 2018).

In New Zealand MPI leads and facilitates animal welfare policy which is governed by the Animal Welfare Act (1999) (New Zealand Government, 1999). An amendment to this Act in 2015 enabled MPI to elevate minimum standards of welfare to directly enforceable regulations. In 2016 the New Zealand Government published the Animal Welfare (Calves) Regulations, specifying measures to improve bobby calf welfare.

Despite MPI claiming that New Zealand has high animal welfare standards, the depredations of the dairy industry in New Zealand are brutal and systemic. Cows are impregnated yearly (often by artificial insemination); cow and calf are separated shortly after birth; and up to two million bobby calves are killed each year. A bobby calf is one that is defined by MPI as "surplus to farm requirements that are typically sent to slaughter aged between 4-14 days" (Ministry for Primary Industries, 2017, p.8). These calves are ones who are not kept for replacement herd or beef and so are killed. Their bodies are mainly used for human consumption, while a smaller percentage is used for pet food (31,00 or 1.6\%). 
MPI (2017) estimated the number of young calves that were processed "in the 2016 season to be just under 2 million calves. This increased from 1.5 million calves in 2008 to a peak of almost 2.2 million calves in 2015" (Ministry for Primary Industries, 2017, p. 8). The number of bobby calves is just under half of all calves born on dairy farms - 20-25\% of heifer (female calves) are raised for replacement and $20-30 \%$ are raised as beef and a small percentage kept as dairy bulls. The rest are bobby calves sent to slaughter. A small percentage are classfied as 'other' - they are killed on the farm or die from natural causes (Ministry for Primary Industies, 2017).

The idea of two million new-born calves being killed for their mothers' milk is repugnant. In addition, cows, highly maternal beings, suffer when separated from their young. Then there are issues specific to the process of domestication. Domesticated farm animals have been bred specifically for their docile characteristics and high productive capacity. Dairy cows in particular are bred for excessive milk production and as a result often suffer painful mastitis. Fitting the non-human animal into the production system of late-stage global capitalism means a continuous honing of their genetics.

Yet the evident cruelties discussed above have been framed as an acceptable act within the West through dominant discourses of animal welfarism. Animal welfare is a hegemonic stance toward animals in liberal democracies and it focuses on the importance of humane treatment of animals. Accordingly, the moral theory of animal welfare holds that animals may be killed to serve human interests as long as it is done humanely. In addition, this theory asserts that "there is no animal interest that cannot be overridden if the consequences of the overriding are sufficiently "beneficial" to human beings" (Francione, 1995, p. 6). All the dairy industry has to do is justify milk production in terms of human interests (e.g. food production, economic markets), and as long as calves and cows are treated and killed humanely there will be limited public resistance.

There is a clear conflict of interest in the dual roles MPI has in ensuring both the welfare of animals and improving sector productivity through maximising export opportunities (Ministry for Primary Industries, 2018). If success on the global market depends on a high animal welfare reputation, then it is not in the interest of MPI to bring the brutalities behind dairying into the public eye.

This is where video activism is so critically important. Through the video footage released in the 2015 Dark side of Dairying campaign the public now become witness to the brutalities of the dairy industry. This puts pressure on MPI to urgently address abuses such as the maltreatment of bobby calves at the abattoir and to redress regulations. Indeed MPI responded to public concern about the treatment of bobby calves following the release of the footage through prosecuting cases of cruelty where they could and by creating stronger regulations. Both measures appealed to the ideology of welfarism.

The 2015 campaign resulted in the conviction of abattoir worker Noel Pirika Erickson on 10 charges of mistreatment of 115 bobby calves at a Waikato slaughterhouse (New Zealand Herald, 2016). Erickson was convicted as a direct result of evidence from Farmwatch footage. In 2016 changes were also made by the Ministry for Primary Industries (MPI) to "strengthen the law around the management and treatment of bobby calves" (Dairy NZ, 2016). 
However, strengthening regulations and convicting offenders does not necessarily lead to long term social change. This point was made by John Darroch of Farmwatch shortly after Erikson was convicted. Darroch commented: "We would have preferred to have seen an investigation into what was behind his action, and what we believe is a systemic failure in the industry. Going after this one guy is not going to help the millions of calves born in New Zealand every year" (Hutching, 2016a).

In $2017 \mathrm{MPI}$, anxious to reassure the public that dairy farming had high standards of welfare, was quick to report success in the area of the care of bobby calves. They stated that while the overall number of calves sent for 'processing' has increased significantly since 2008, there has been a marked decrease in calf mortality before they are killed (from 0.68 in 2008 to 0.25 in 2016) (Ministry for Primary Industies, 2017). This is regarded by MPI as a sign of increasing welfare conditions along the supply train, including farmers, transporters, sale yards and processors. They attribute this to industry and government groups focusing on bobby calf welfare and communicating the importance of adherence to the new regulations pertaining to bobby calf treatment (Ministry for Primary Industies, 2017).

The above section clearly illustrates the importance of video footage and media in challenging the dominant welfarist discourse of the industry and the governing bodies that support it. In the case of the Dark Side of Dairying campaign, the shocking video footage of calves being bludgeoned, kicked and thrown at an abattoir garnered media attention which quickly went global. Garrett Broad (2016) argues that media attention is a critical strategy for animal rights activists. "Visuals of dead or near-dead animals often acquired through undercover means - play into the interests of media producers who rely on dramatic footage and headlines as a hook to engage audience interest and provoke public discussion through affective engagement" (Broad, 2016, p48).

\section{An historical genealogical analysis of farming discourse in New Zealand}

This section provides a critical discourse analysis of dominant cultural narratives that shape the depiction of dairy farming. These narratives are shaped and disseminated by dominant legal, media, educational and economic institutions. It is these very narratives that activist video footage aims to counter. Witnessing is, in the words of Peters (2001) "an extraordinary moral and cultural force" for social change.

Despite living in an agricultural country many people in New Zealand do not necessarily have direct contact with farmed animals. Experience of farm life may be limited to glimpses of animals in paddocks from the roadside which reveal what are often perceived as naturalized lives. Cattle graze seemingly contentedly on lush grass, an image that dairy giant Fonterra is keen to capitalize on through TVCs and other advertisements depicting cows grazing on prime real estate (Fonterra, 2016a). The idea that farmed animals have a good life in New Zealand rests on the idealization of agriculture and rural life (Potts, 2013).

The window into the lives of dairy cows and farm workers in New Zealand is partial. It is obscured not only by physical barriers (rural isolation, farm gates, milking sheds) but also by ideological mechanisms. These include dairy industry propaganda that articulates ideologies of farming as a rural idyll.

Identity formation in New Zealand is still linked to our colonial image of the 'hard working farmer', and the notion of an idyllic country life. Philip Armstrong (2017) 
argues that the image of New Zealanders as farmers is a fantasy of the colonial era that has endured until the present day. Early colonists in New Zealand were often motivated through immigration schemes to build new lives different to the polluted and harsh life of industrial era England.

Armstrong (2017) argues that this anti-industrial Romanticism is linked to Arcadian imagery,referring to "the ancient tradition of portraying agricultural life as a utopian form of existence" (p.2). He cites various examples of poetry as well as paintings from popular romanticism where pretty milkmaids milk cows. He also refers to Thomas Hardy's 1892 novel Tess of the d'Ubervilles: a Pure Woman Faithfully Presented (Hardy, 2005). Armstrong (2017) has quoted at length from Hardy's novel and it is worth repeating here. Tess arrives at the farm at milking time:

The red and white herd nearest at hand, which had been phlegmatically waiting for the call, now trooped toward the steading in the background, their great bags of milk swinging under them as the walked...They were the less restful cows that would be stalled. Those that would stand still on their own will were milked in the middle of the yard, where many of such better behaved ones stood waiting now... Their large veined udders hung ponderous as sandbags, the teats sticking out like the legs of a gipsy's crock; and as each animal lingered for her turn to arrive the milk oozed forth and fell in drops on the ground.

-Thomas Hardy, 1892

Tess of the d'Ubervilles also recounts the fantasy of countless generations working the land and the fertile soil. These ideas and the notion that cows need to be milked and are grateful to humans for doing this, evident in the above passage, is still evoked today in the Fonterra TVCs. Human-nature intimacy is a strong tenet of Romantic thought and literature.

Dairy farming in New Zealand rests upon the idea of an imagined domestic contract between humans and livestock, whereby both parties are regarded as being engaged in a reciprocal relationship (Te Vlede, Aarts, \& Van Woerkum, 2002). Accordingly, the dairy animal and the farmer are perceived to participate in mutually beneficial relations where the farmer gives food, shelter and care in return for what is taken from the animal. This idea is one of the building blocks of a larger discursive configuration that operates to obscure the suffering of domesticated farm animals.

Video activism can disrupt this social imaginary of the contented dairy cow - caring farmer dynamic through engaging audiences with specific visual encounters of suffering. This video footage - https:/vimeo.com/277437126/ce06d0db0e captured by Farmwatch and released in June, 2018 demonstrates a New Zealand sharemilker brutally beating cows with steel pipes on their faces, legs and backs in the milking shed. Farmwatch note in the video that MPI had visited this farm after complaints and not taken any action.

The brutality demonstrated in the above video counters ideologies that serve to present the dairy cow as a content animal living in a natural symbiotic relationship of mutual benefit with the farmer. Rather, the dairy cow is reduced to an animal who must 
be dominated and coerced into an unnatural relationship with the farmer. Here in this video we see the dairy cow as a frightened and hurting animal, a subject of pain and fear.

Not all farmers subject their animals to the brutality evident in the video above. Nonetheless, it is clear from this video that such behaviours exist to a greater of lesser degree within the dairy farming industry in New Zealand. Animal rights groups SAFE and Farmwatch have used such videos to pinpoint the inadequacies of MPI in addressing such abuses. They argue that the current system is inadequate to deal with these hidden incidents of extreme abuse and call for an independent animal welfare watchdog.

The dairy industry reduces the cow to a mere singular living cog in a vast machine. The animal-as-machine metaphor is an ideological mechanism that reduces the non-human animal to an object, much like a stone. The increase in technological applications to dairy farming has served to mechanise the industry, taking it ever further from its Arcadian roots even while it evokes them.

New Zealand dairy farming has followed many of the technological trends of the Western world, including the use of milking machines since 1960, and more recently milking robots. The mechanisation of dairying is significant because it alters human perception of the dairy animal. When a farmer or farm employee milks a cow they attach a milking machine (a pump connected though tubes to teat cups) to a cow's teats. The human and cow are now connected in a relationship mediated and defined through technology. The milk is not seen for what it is - the food intended for the cow's calf - rather farmers regard milk as a commodity to be 'harvested'. (Driessen \& Heutinek, 2015). The milk flows in a unilateral direction from the cow to the human through the mediation of a machine, distancing the farmer even further from the absent calf that would ordinarily be with the cow suckling. The machine replaces the calf, draining the cow of her milk that her body continues to produce for the absent offspring.

The reality of the lives of dairy animals in New Zealand is (mis)represented through enduring cultural narratives of the importance of farming to the 'kiwi identity'. Annie Potts (2013) suggests that despite the myth of farmers as "the epitome of kiwiness", many New Zealanders are not farmers and are heavily urbanised (p.228). Furthermore, while real farmers forget the absent calf (now replaced by the suckling machine), the lives of farm animals are becoming increasingly invisible to many New Zealanders.

It is in the interests of the dairy industry to nurture these images of hard working kiwi farmers and the Arcadian rural idyll. These dominant accounts of dairying have become entrenched in the New Zealand cultural psyche.

The video footage from the Dark Side of Dairying Campaign and the recent milking shed footage aimed to unsettle these dominant accounts by shedding light on dairy. The public now become witness to the empty dark spaces where dairy animals suffer unseen. Through viewing video footage of dairy cruelty first-hand the public are engaged in the act of witnessing and this is a "distinct mode of perception: "we cannot say we do not know" is its motto. (Peters, 2001, p.708). Through the act of witnessing, the person now becomes "responsible in some way to it." (Peters, 2001, p.708) Their explanatory discursive framework around dairying becomes unsettled.

The capture of animal rights violations by activists using video is contingent on audience engagement. (Ristovska, 2016). Sandra Ristovska (2016) argues that activists use video images of atrocity and violations to 'interpellate audiences', influencing their opinions and actions. 


\section{Fonterr(a) or Fonterr(or):}

The process of engaging audiences through video activism with the hope of generating social change involves political struggle. The animal agricultural industry regards undercover video footage of animal cruelty as a 'public relations' threat. They are themselves engaged in their own attempt to shape public knowledge on farming and alleigence to the status quo. This has become particularly important in times of intensification of dairy production. In the age of advanced neo-liberal capitalism dairying (like other farming practices) becomes increasingly fast-paced and intensified. As noted in the first section of this paper, dairy farming in New Zealand has grown and intensified in the last three decades to compete on the global market. Fonterra reflects the neo-liberal agenda of participation in the globalised free market. For most of its history dairy farming in New Zealand was focused on exporting to the United Kingdom 'home' market. However, since its merger in 2001 Fonterra has focused on expanding its international market.

Fonterra is New Zealand's largest company and a trend-setter on the global trading scene. In 2008 Fonterra "conducted the world's first global Internet trading of dairy products" (Gray \& Le Heron, 2010, p. 3). Stuart Gray and Richard Le Heron (2010) comment that Fonterra is now a "truly global actor" (p.7). New Zealand is important to Fonterra as its manufacturing base, milk supply source and the location of its shareholders - although $20 \%$ of its milk supply now comes from overseas sources.

The recent production of Fonterra advertisements and other propaganda has become central to meaning-making around ourselves-as-New Zealanders.The Fonterra television commercials employ a number of tropes used widely across much television advertising and which sit comfortably within the iconography used to sell 'farm products' such as drenches, fertiliser additives, pesticides and even insurance policies. Common to these TVCs is the idyllic portrayal of farm life, an often humorous connection to the farm animals, a celebration of the importance of farming to the economy, the stereotypical toughness and resilience of the hardworking farmer, the centrality of the image of the nuclear family, and the privileged role of science and technology. Fonterra advertisements like Our Pasture - Trusted Goodness and The Fonterra Story are central to cultural meaning making around dairying in New Zealand (Fonterra, 2013; Fonterra, 2016b). The Our Pasture - Trusted Goodness advertisement signifies the importance of Fonterra as a trusted brand that feeds families and fuels the economy.

The idea of trust has been a constant theme that Fonterra is determined to have associated with its brand. In 2016, Fonterra launched several advertising campaigns (Hutching, 2016a). All branded Fonterra products were stamped with a seal with the words "trusted goodness". This marketing move was carefully crafted to appeal to a diverse international market who have varying concerns about the safety and ethics of dairy production. Hutching (2016b) explains, "United States consumers will be told the product will bear a "non-GMO" claim, in China it will be "grass-fed" and for other markets "cared-for cows" will appeal to people with animal welfare concerns". The backdrop in these commercials of New Zealand dairy farms is one of lush green grass, rolling hills, idyllic landscapes with farmers walking among their cows and is distinctly Arcadian.

The "trusted goodness" branding was followed by the launching of an advertising campaign fronted by former All Black captain and now media 'influencer' Richie 
McCaw. Called \#4.31 AM these advertisements centred around McCaw talking to farmers in a series of interviews in a bid to dispel myths about dairying and build an understanding of what Fonterra is all about (Fonterra 2018a, \#4.31 AM).

Fonterra makes liberal use of children in conveying its message of serving local and global communities. The use of children not only conveys the message of innocence, purity and simplicity but cements the idea that dairy products are essential for human wellbeing, thus an anthropocentrism that is common to all advertising that employs images of the nuclear family. These images attempt to win the hearts and minds of children and parents, conveying the idea of community working together for the common good and building connections between people. The animals are party to this cause. A Fonterra TVC entitled Fonterra - from the grass to the class suggests that the cows are full of milk and waiting at the gate for the farmer to milk them in the morning. This TVC clearly promotes the idea of a partnership between farmer and animal and the links to cultural texts such as Hardy's Tess of the d'Ubervilles are reinforced.

Several key discourses emerge from this series of advertisements and are categorized below.

Acadian rural idyll discourse:

- Generations of hard working farmers working the land;

- The goodness and naturalness of dairy;

- Dairy farming is conveyed in terms of 'life's work and passion' and 'simplicity';

- Fonterra as owned by New Zealanders (not a faceless corporate but a community)

- Farmer pride in their product;

- Milk as wholesome and natural nutrition;

- Passion and a way of life;

- Pure, simple and idyllic country life of yesteryear;

- Water, sunlight, soil = quality product;

- Farms as an extension of the person (unity /intimacy between land and farmer);

- Cows as part of family.

Welfarist discourse:

- Cows as cared-for animals who are well fed on pasture;

- Cows treated kindly and willingly in partnership with the human project;

- Contented healthy cows having a good, stress-free life;

- Farmers have a duty of care to the animals;

- Technology as an aid to welfare;.

Western science and technological innovation discourse:

- Fonterra is using the best science and technological innovation;

- High hygiene standards;

- The latest advanced food technology used to 'improve' on nature's goodness;

- Science as an elite and privilged discourse working for the good of humanity.

Sustainable development discourse:

- Farmers as caring environmentalists doing restoration work (as counter to the growing discomfort and awareness of the environmental damage of farming);

- Farmers have a duty of care to the environment;

- Fonterra does good work in the community (milk for schools, riparian planting programmes); 
- Fonterra as a co-op of farmers who are prideful and caring and involved in local communities;

- Caring communities helping future generations thrive ("dairy for life").

Patriotic discourse:

- Fonterra as central to New Zealand identity politics;

- Agrarian identity and connection to the land;

- "That is what being a Zealander is all about";

- "We care about New Zealand".

Market discourse:

- Fonterra as the best milk producer in the world (faith in the market);

- Fonterra building economic networks globally;

- Focus on a family business (a co-operative, not a corporate);

- Consumer trends for natural products;

- Emphasis on expansion and growth.

The above discourses are, in reality, not clearly demarcated and contained within labelled categories. The advertisements use the various ideologies by interlacing them to make an ever-evolving discursive position on dairy farming in New Zealand. For example, The Arcadian rural idyll ideologies are articulated with technological innovation and environmental sustainability in powerful ways. In one advertisement entitled Technology backs up our instinct (Fonterra 2017b, Technology backs up our instincts) it is suggested that:

The cow shed knows who the cow is, and that milk is known all the way through the production process. In fact, we even know which paddock the milk came from. Each of the animals is individually identified, we know who they are, we know who their parents are, we know what they like to eat for breakfast. Technology more than anything allows us to achieve what we set out to do in terms of caring for our land. I think Grandad would be absolutely amazed that you carry a phone in your pocket to control things on your farm.

Fonterra, 2017b

This is a cow shed with a difference - it can 'know' the cow. In this single advertisement there are three key ideologies: a) technological innovation as an unmitigated good; b) generations of farmers working the land; c) environmental sustainability. The advertisement signals to the consumer that it is a pure natural product backed up by the latest technology and knowledgeable farmers, and with animals who have individual attention despite increases in herd size. The connections that are made between these ideologies operate to co-ordinate the interests of Fonterra in establishing a consensus among consumers (as the target audience) in support of dairy farming.

This advertisement also signals that the milk machine now knows the cow, but the machine conveys the individual needs to the farmer and so the farmer (as an intergenerational caring man of the land) now becomes the innovative up to date technology. Links to Donna Haraway's notion of the post-human as machine enabled are worth noting here (Haraway, 1990). The message is that even though dairy farming is now 
mechanised, the technology is somehow human and the human is technological. The cow shed is so technologically brilliant it recognises the cows and conveys their vital details to the farmer. It is almost as if the farmer and the machine are one - a cybernetic organism (Haraway, 1990).

The McCaw advertising campaign has continued with Ritchie's Milk Run - Fonterra Milk for Schools (Fonterra 2018a, Ritchie's Milk Run - Fonterra 2018b Milk for School). With McCaw Fonterra has achieved a level of credibility with New Zealand audiences that could be said to be complete. McCaw, in his new incarnation as helicopter pilot is filmed descending from the skies not unlike Jesus in the Second Coming to deliver the miracle liquid of the gods to the chosen schoolchildren of Godzone.

By applying a Barthesian semiotic analysis - denotation, connotation and myth (Barthes 1957) - to these Fonterra TVCs it is possible to detect a number of disturbing similarities to the films and propaganda of the Nazi era, most notably the films of Leni Riefenstahl as discussed by Susan Sontag (Sontag, 1980). The famous opening sequence of Riefenstahl's Triumph of the Will, for example, has The Fuehrer descending from the skies like a classical god in his silver flying chariot/aeroplane to appease the adoring crowd who await him in a state of rapturous applause and worship (Riefenstahl (1934).

In other Fonterra sequences McCaw is shown in friendly dialogue with dairy farmers as they wander around the farm and its milking sheds (Fonterra 2016a, Our Pasture Trusted Goodness). He nods in agreement, 'knowing' of their challenges and observing of their hardships. He is one of them, yet his central focus in the frame and his charisma as a famous All Black defines him as the "benign Super-Spectator", as Sontag calls Hitler in Riefenstahl's Olympia (Sontag, 1980). This is not to say that McCaw is in any way like Hitler, but the iconography of his representation is similarly constructed. McCaw becomes the charismatic leader in this affirmation of community, a noble specimen of physical and mental prowess and the upholder of the Kiwi values identified with the Fonterra brand: the strive to perfection, the sanctity of courage, the boldness of goals and mastery over the land and all its animals.

Fonterra's grip on our hearts and minds as New Zealanders has even found itself in the halls of academia. Stuart Gray (General Manager of Global Trade at Fonterra Co-operative) wrote a journal article with Richard Le Heron in the New Zealand Geographer in 2010. They sought to locate Fonterra at the centre of New Zealanders' collective vision. In a statement more akin to advertising propaganda than an academic journal article they write, "We begin with two propositions: thinking about New Zealand is to think about Fonterra; thinking about Fonterra is to think about New Zealand" (Gray \& Le Heron, 2010, p. 1).

That Fonterra promotes a kind of agrarian nationalism is fairly obvious from their TVCs. Armstrong (2017) has done some important work in drawing attention to this aspect of their television iconography, even if he manages to hold back from making the 'blood and soil' analogy. If we can agree with John Ralston Saul that contemporary globalism is "fascism without the jackboots" (Saul 1999) we can say that Fonterra's exploitation of rural settler identity is not so much their version of Lebensraum but rather the transfer of vast amounts of international capital, derived as it is from the suffering of vast numbers of animals. Fascism's concept of "domination and enslavement" (Sontag 1980) is thus transferred, via the brutality of market economics and the Cartesian view of the mechanistic animal, to the operations of the animal industrial complex. 
The enduring imagery of New Zealand as an Arcadian paradise with up-to-date technological practices and happy cows has been reproduced through Fonterra propaganda. In all their advertisements, Fonterra never mention the deaths of up to two million bobby calves. These calves remain invisible, as if they never existed. Their tiny and tormented bodies, now dead and processed, come to life again through the lens of the video camera. Cows also suffer on dairy farms and this is another aspect that has been covered by activists. The Fonterra advertisements never depict the dairy cow in all her grief as she struggles to come to terms with the loss of a calf each year.

Farmwatch and SAFE use the videos they make to re-insert the suffering cow and calf into the narrative and challenge Fonterra's storytelling. Video footage is used as a form of 'counter-advertisement' for dairy farming and its products. The activist work of Farmwatch and SAFE involves turning the tables on Fonterra and has even taken the form of a parody on one of the advertisements using footage of dairy cruelty. The Fonterra advertisement entitled Our Cows: Trusted Goodness (Fonterra 2016b, Our Cows - Trusted Goodness), was parodied and published by SAFE and can be viewed here https://vimeo.com/264386193. The original Fonterra advertisement discussed how "happy healthy cows produce good milk" and the farmers talked about singing to the cows, giving them individual names and patting them. On their Facebook page SAFE called this advertisement a "public relations stunt" and argued that it "doesn't change the fact that investigations have repeatedly exposed both deliberate and inherent abuse of cows and their calves". With the by-line: "Seen Fonterra's new 'animal welfare' ad? We fixed it for them", SAFE published a parody with footage showing the reality of life on dairy farms - bobby calves hurled onto trucks and trailers; alone and dying in a cage by the roadside; cows bawling for their calves as they chased a trailer the calves were in. The parody re-inserted the dead bobby calf back into the picture (SAFE, 2016).

The violations experienced by dairy animals are framed within welfarist/progressive ideologies backed up by a Cartesian view of animal-as-object. Through video footage activists seek to portray the animal as a subject of her own existence, to regard her as a non-human person with the right to life on her own terms. The aim is to expand the public imagination, not simply to highlight isolated instances of cruelty. But to generate critical thought and discussion about the systemic cruelty which is part of the industry.

Garrett Broad describes this approach as "powerful "image event" tool for exposing ... the brutal realities of industrial animal production in order to shift the public consciousness" (Broad, 2016, p.48).Indeed. an important goal of video activism is to make clear the connections between the industrial farming of animals and the historical horrors of human slavery and genocide. A project that is largely educational, it is activism aimed at exposing both the workings and the similarities of ideology that maintains both speciesism and racism.

\section{Speciesism and welfarism: Ideologies of dominance}

Timothy Pachirat (2011) argues in his book Every Twelve Seconds that the lives and deaths of animals in the animal industry are concealed from humans through a variety of physical, social, and linguistic mechanisms. He calls this a "politics of sight". Many of these have been discussed above, including the ideological framing of animals as mere commodities to be traded on the market place and as objects of consumption. These speciesist assumptions become articulated with welfarist ideologies that animals 
are well cared for and happy in the farming industry. These ideologies are mediated through TVCs, legal systems and education. They form what Broad (2016) calls "the social production of ignorance. "(p. 44).

As discussed above, the dominant ideology within New Zealand's policy on farmed animals is legal welfarism. MPI provides an illustrative example of how legal welfarism is applied in practice when addressing issues of animal cruelty in farming. The institutionalised cruelty that dairy animals are subject to (such as cow-calf separation/killing calves) is rendered invisible as these are considered necessary for dairy to continue. They are also regarded as within the interests of humans (nutrition/strong economy) and so are not categorised as unnecessary suffering.

Legal welfarism is underpinned by assumptions based in speciesist logic. Speciesism (a term coined by Peter Singer) is a prejudice against animals based on their perceived membership of a species. The ideology of speciesism is part of the Western Enlightenment and humanist tradition that places animals on a lower scale ontologically (Bell, 2011).

At the root of this prejudice toward animals is what Eric Fromm (2007) calls the "great illusion" of the Enlightenment/industrial age. Enlightenment thought includes the notion of 'species', which is not a biological fact but rather "an ontology and epistemology of hierarchical domination that energises structures of human supremacy over animals (Rowe, 2011, p. 3). The categorization of non-human animals as 'lesser than' because they are said to lack reason (considered a peculiarly human attribute) operates to establish a binary between rational humans and non-rational animals (Weisberg, 2011).

As an ideology, legal welfarism is based on a speciesist ontology, for it implicitly accepts the notion of human interests ahead of those of animals. Within the terms of this logic, animals may be considered as a resource for humans, but that we should mitigate any 'unnecessary suffering' through laws against inhumane treatment. MPI takes a strongly welfarist stance. They state that: "Animals play an important role in many New Zealanders' lives - they offer food and fibre, income and companionship, education, research and entertainment".

A fundamental assumption at the basis of legal welfarism is that animals are private property (Francione, 1995). This means that within this framework they cannot possess rights but become "objects of the exercise of human property rights" (Francione, 1995, p. 4). Animal welfare laws are put in place to balance the interests of the animal against human mistreatment. However, as Gary Francione (1995) states, the legal system is "completely unresponsive to this moral sentiment and permits any use of animals however abhorrent" (Francione, 1995, p.4).

This is clearly evident in the case of bobby calves who, stripped of any defences or rights, have their lives ended virtually before they have begun. The new regulations put in place by MPI in 2016 do little to mitigate the suffering of these defenseless young animals (New Zealand Government, 2016). According to these regulations, it is legal to transport a four to ten day old calf for up to $12 \mathrm{~h}$ from the start of the destination until the end. In addition these calves can legally go for $24 \mathrm{~h}$ without sustenance before they are slaughtered (New Zealand Government, 2016). These are young mammals with a strong desire to suckle, who would naturally feed from their mother. Those involved in the bobby calf supply chain are urged to give the calf colostrum if $s /$ he has gone for 
$24 \mathrm{~h}$ without feed. Then, chillingly, the law states that it is important to "ensure that the calf is slaughtered as soon as possible after it is fed" (New Zealand Government, 2016).

Calves are literally nurtured with one hand and killed with the other in the name of their welfare. Everything that is done to bobby calves from the moment they are born is actively working toward their demise. The profound distress they must experience from the moment they are separated from their mothers is minimised and dismissed by a welfarist worldview that refuses to see their suffering.

Welfarist models serve the interests of animal agriculture in an industrialised late-stage capitalist era in that they support the notion of private property and legal rights to use that property. Animals are private property who can be used in pursuit of the profit seeking motive of capitalism. They become objects and their bodies become commodities for exchange on the market. A cow's capacity to produce milk is exploited in the interests of profit, and her calf is killed. She has no legal recourse or status apart from welfare laws which, as demonstrated above, do little to protect her, or her calf.

This is central to the process of governmentality which includes the formation of subjectivity and self-governance. Foucault's concept of neoliberal governmentality refers to the process through which governments produce citizens who conform to market-based norms (Larner, 2000); or in this case, a market based, technological approach to farming animals based on exponential growth and intensification of the dairy industry. Treating animals and their excretions as commodities to be traded on the global market place is a market-based norm. Public perception of high animal welfare standards in the dairy industry are critical to its ongoing success in the market place.

The public places trust in the legal system to keep the animals happy and content. Cows may be perceived as desirous of being milked to relieve the pressure on their udders, grazing happily on green pastures until they have 'one bad day' where they are killed. This image obscures the excruciating reality of their lives just as readily as windowless sheds.

They have little to no intrinsic value ascribed to them and their extrinsic worth is conflated with both their reproductive and their productive capacity. "They just have to be, in an excremental, existential void, until we kill them" (Davis, 2011). Non-human animals that are farmed in dairy operations in New Zealand become the subject of the logic of this deadening human-imposed incarceration.

\section{Conscientization}

Video activism seeks to counter the concealment of animal suffering in animal agriculture by making institutionalised cruelty visible. As Pachirat (2011) argues this strategy is underpinned by the assumption of "power through transparency", and the idea that $[u]$ nder the light of everyone's gaze, under our gaze, they will wither and shrivel up, scorched by the heat of our disgust, our horror, our pity, and the political action these reactions engender." (p. 247). However, as Pachirat (2011) goes on to argue, the work of those who seek transparency and aim to make animal suffering visible also, paradoxically motivates the animal agriculture industry to reinforce their ideological dominance. This is evident in the Fonterra TVCs and the work of MPI to convince the public that they are improving animal welfare. 
Pachirat's (2011) message is that the politics of sight, whereby the repugnant is made visible, is complex and the assumption of the ideal of transparency in mobilizing social change should not be taken for granted. We need to think more deeply about "which conditions, contexts, and types of making visible are likely to be more politically transformative." (Pachirat, 2011, p. 255).

Like Pachriat, Peters (2001) also suggest that despite its potential power, witnessing or 'making visible' has fragilities. This is because it is based on the presupposition that there is a discrepancy between the person who holds the knowledge (attempting to convey it through taking and showing video footage) and the 'ignorant other' (witness of video footage). There is, in short "an epistemological gap" and we cannot just expect conscientization of the oppressive realties of dairying to occur through witnessing alone (Peters, 2001, p.710).

We suggest that the videos taken by Farmwatch and SAFE are more closely used with educational programmes based on the process of conscientization. The idea of conscientization is grounded in the work of Paulo Freire and focuses on development of critical consciousness of social and political contradictions, with the goal of taking action against social injustices (Freire, 1970/2005). The videos taken by Farmwatch and used by SAFE facilitate the development of a critical awareness of the animal oppression that is at the root of the dairy industry.

In a similar vein Heesoon Bai argues for an education that transforms our consciousness from a state of psychic numbing (Bai, 2009). The Cartesian perception of nature as machine and animals as objects has been seared into our collective consciousness. Bai suggests that we project this perceived reality onto the world and treat it in destructive ways. Video activism against dairying is part of a bigger animal rights worldview that challenges this perceived reality. The concept of 'witnessing' is key to this shift in perception.

There is more work to be done on the pedagogical possibilities of using activist footage in such a way that will empower the public to deconstruct the processes through which living animal bodies are transformed into discursive forms and physical objects. The focus here is on moving beyond the hierarchy and the separation between human and non-human nature, to the sense of their organic unity, to the one-ness of the living planet. A key goal of animal rights video activism is to draw attention to the environmental catastrophe that is industrial farming. The burgeoning public awareness of polluted waterways, nitrogen fixation, fertiliser run-off, soil depletion, deforestation, biodiversity loss and greenhouse gas emissions from industrial animal agriculture worldwide is testament to what has already been achieved by activists using both mainstream and alternative platforms to disseminate their message. By highlighting equally the non-human animal's sentience and the environmental damage caused by their entrapment and exploitation on such a vast scale, it is hoped the public may make fundamental changes both on a personal level and on the level of placing political pressure on governments. The ultimate aim, of course, is to transition to a sustainable and cruelty-free plant-based economy.

\section{Conclusion}

The above discussion has attempted to demonstrate how the dominant narratives of the dairy industry - that the industry's ideological frameworks support taken-for-granted understandings through which dairy cows and calves are exploited - can be countered by an 
animal rights video activist practice. The primary focus of this activism is the sentient dairy animal which has become increasingly commodified and valued in terms of its usefulness as a source of further economic growth. In other words, the video activist practice attempts to bear witness to the instrumental value of dairy animals being given precedence over all other valuations which works to justify the overriding worldview that the ongoing exploitation of non-human nature is 'necessary' to the human project. Within this discourse, the very idea that dairy animals might be given equal consideration to those of humans becomes unthinkable. The camera witnessing them as being turned into objects, to be valued according to their use and to be bought and sold in the global capitalist market place provides the central content of animal rights video activist footage.

The strength of video footage is that it provides a counter story to dominant narratives and demonstrates the brutality and institutionalized cruelty experienced by dairy animals. It aims to make the unthinkable - the rights of animals in farming thinkable. Once something is thinkable it becomes a source of conscientization through exploration of the unjust and exploitative mode of production that supports it. Video footage of animal cruelty in the dairy industry captures the public imagination and opens public discussion. This is achieved by mobilizing media to transform audiences into "witnesses and publics" (Ristokska, 2016.p.1039).Critical discussion by the public is necessary to generate the exercise of political agency.

However, the use of a politics of sight in the service of transformative social change is complex. The relationship between witnessing repugnant practices in the diary industry and mobilizing public resistance is not given. We suggest further research is needed on the use of activist videos in education based on the idea of conscientization.

Funding

Covered by the Association for Visual Pedagogies.

\section{Authors' contributions}

LT contributed the bulk of the research including analysis of video activism and critical discourse analysis of dairying in New Zealand. PJ contributed semiotic analysis of dairy industry advertising. He also contributed to editing and structural work and key ideas within the article. Both authors read and approved the final manuscript.

\section{Competing interests}

The authors declare that they have no competing interests.

\section{Publisher's Note}

Springer Nature remains neutral with regard to jurisdictional claims in published maps and institutional affiliations.

Author details

${ }^{1}$ Independent Consultant, Auckland, New Zealand. ${ }^{2}$ Independent Consultant, Hamilton, New Zealand.

Received: 2 June 2018 Accepted: 10 July 2018

Published online: 09 August 2018

\section{References}

Armstrong, P. (2017). Welcome to the milk machine. Dairy farming as New Zealand's industrial revolution. "Dear Dair' Symposium (pp. 1-15). Christchurch: Conference proceedings

Bai H (2009) Reanimating the universe: environmental education and philosophical animism. In: McKenzie P, Hart P, Bai H, Jickling B, Creskill (eds) Fields of green: Restorying culture. Hampton press, pp 135-155

Barthes R (1957) Mythologies. Paladin Grafton Books, London

Bell A (2011) The dialectic of anthropocentrism. In: Sanbonmatsu J (ed) Critical theory and animal liberation

Broad G (2016) Animal production, Ag-gag Laws, and the social production of ignorance: exploring the role of storytelling. Environmental Communication 10(1):43-61

Dairy Companies Association of New Zealand, 2018 https://www.dcanz.com/about-the-nz-dairy-industry/

Dairy NZ. (2016). MPI announces new regulations for bobby calves. Retreived on 30.6.2018 from https://www.dairynz.co. nz/news/latest-news/mpi-announces-new-regulations-for-bobby-calves/ 
Davis K (2011) Procrustean solutions to animal identity and welfare problems. In: Sanbonmatsu J (ed) Critical theory and animal liberation. Rowman and Littlefield Publishers, Retrieved from ProQuest Ebook Central https:// ebookcentral-proquest-com.ezproxy.waikato.ac.nz/lib/waikato/detail.action?doclD=730743

Driessen C, Heutinek L (2015, March) Cows desiring to be milked? Milking robots and the co-evolution of ethics and technology on Dutch dairy farms. Agriculture and Human Values 32(1):3-20

Farmwatch. (2015). The dark side of dairy. Retrieved from https://vimeo.com/146749967

Fonterra. (2013). The Fonterra story. Retrieved from https://www.youtube.com/watch?v=9_k3OERgDvs

Fonterra. (2016a, November 23). Our Cows - Trusted Goodness. Retrieved 4 7, 2018, from https://www.youtube.com/ watch? $v=h X A 9 d_{-}-L S L w$

Fonterra. (2016b, November 3). Our pasture - trusted goodness. Retrieved from https:/www.youtube.com/watch?v=YxDu6MQi_eE

Fonterra. (2017a, October 28). Dairy loved around the world, made by many. Retrieved 4 7, 2018, from https://www. youtube.com/watch? $v=$ fnzk3er6nFQ

Fonterra. (2017b, April 20). Technology backs up our instincts. Retrieved from https:/www.youtube.com/watch?v=p09nTLPRUsY

Fonterra. (2018a, March 7). \#4.31 AM. Retrieved 4 7, 2018, from https://www.youtube.com/redirect?redir_token= ifx1PCJ2xwsWBQzir-YQBpiTS4p8MTUyMzQyNTkyMEAxNTIzMzM5NTIw\&q=http\%3A\%2F\%2Fwww.fonterra. com\%2F431am\&event=playlist_description

Fonterra. (2018b, March 9). Ritchie's milk run - Fonterra milk for schools. Retrieved from https://www.youtube.com/ watch? $=$ K8u0ACbwIBI\&list=PLzXDubftJD9Fy0yMB6I2NbyTf16CiiocZ

Foucault M (1972) The archaeology of knowledge. Routledge, London

Francione G (1995) Animals, property and the law. Temple University Press Retrieved from https://ebookcentralproquest-com.ezproxy.waikato.ac.nz/lib/waikato/detail.action?doclD=713722

Freire P (1970/2005) Pedagogy of the oppressed. Continuum, New York

Gray S, Le Heron R (2010) Globalising New Zealand: Fonterra co-operative group, and shaping the future. New Zeland Geographer 66:1-13

Hardy T (2005) In: Gatrell S, Grindle J (eds) Tess of the D'Urbevilles. Oxford University Press, Oxford

Hutching, G. (2016a, November 4). Fonterra launches global 'trusted goodness' campaign. Stuff. Retrieved from https:// www.stuff.co.nz/business/farming/86119711/fonterra-launches-global-trusted-goodness-campaign

Hutching, G. (2016b, November 8). Farmwatch unhappy at prison sentence for animal abuser. Retreived from https:// www.stuff.co.nz/business/farming/86213468/farmwatch-unhappy-at-prison-sentence-for-animal-abuser

Larner W (2000) Neo-liberalism, ideology, Governence. Studies in Political Economy 63:5-25

Livestock Improvement Corporation Limited \& DairyNZ limited. (2017) Dairy Statistics 2016-2017 Retrieved from http:// www.dairynz.co.nz/dairystatistics

Ministry for Primary Industies (2017) Mortality rates in bobby calves. New Zealand Government, Wellington Retrieved from https://www.mpi.govt.nz/dmsdocument/16501-mortality-rates-in-calves-2008-to-2016

Ministry for Primary Industies. (2018). About Us . Retrieved from https://www.mpi.govt.nz/about-us/

Ministry for the Environment; Statistics New Zealand. (2018). New Zealand's Environmental Reporting Series:. Retrieved March 6, 2018, from http://archive.stats.govt.nz/browse_for_stats/environment/environmental-reporting-series/ environmental-indicators/Home/Land/livestock-numbers.aspx

Mulet-Marquis S, Fairweather J (2008) New Zealand farm structure change and intensification. Lincoln University. Canterbury, Agribusiness and Economics Research Unit (AERU)

New Zealand Government. (1999). Animal Welfare Act. Retrieved March 7, 2018, from http://www.legislation.govt.nz/ act/public/1999/0142/latest/DLM49664.html

New Zealand Government. (2016). Animal Welfare (Calves) Regulations 2016. Retrieved from http://legislation.govt.nz/ regulation/public/2016/0170/latest/whole.html

New Zealand Herald (2016, November 8) Cruelty to bobby calves results in jail time after appeal. Retreived 2.6.2018, from https://www.nzherald.co.nz/nz/news/article.cfm?c_id=1\&objectid=11743817

Pachirat T (2011) Every twelve seconds. Yale University Press, London Retrieved from http://www.jstor.org.ezproxy. waikato.ac.nz/stable/j.ctt5vm69m

Peters J (2001) Witnessing. Media, Culture and Society. 23:707-723

Potts A (2013) Consuming animals. In: Potts A, Armstrong P, Brown D (eds) New Zealand book of beasts: Animals in our culture, history and everyday life. Auckland University Press, Auckland, pp 226-245

Riefenstahl L (1934) Triumph of the will. Synapse Films 2015

Ristovska S (2016) Strategic witnessing in the age of video activism. Media, Culture and Society 38(7):1034-1047

SAFE. (2016, December 8). Fonterra - Dairy for life? Seen Fonterra's new 'Anim Welf' ad? We fixed it for them. Retrieved 4. 7. 2018, from https://www.youtube.com/watch?v=c5isbj-yMxo

Saul, John R. (1999). The unconscious civilisation, Free press

Sontag S (1980) Under the sign of Saturn. The Noonday Press, New York

Te Vlede H, Aarts N, Van Woerkum C (2002) Dealing with ambivalence: farmers' and consumers' perceptions of animal welfare in livestock breeding. J Agricul and Environ Ethics 15:203-219

Weisberg Z (2011) Speciesism as Pathology. In: Sanbonmatsu J (ed) Critical theory and animal liberation 